\title{
Emerging Dimensions of Women Entrepreneurship: Developments \& Obstructions
}

\section{Sonal Sharma}

Dr. S. Radharkrishnan Post Doctoral Fellow, University Grants Commission, New Delhi, India

Corresponding author: prof.sonalsharma@gmail.com

\begin{abstract}
Women entrepreneurship has been recognized as an important factor of economic development. Women entrepreneurs can originate new jobs for themselves and others. However, they still represent a minority of all entrepreneurs. Women is an essential part of key economic activities and for nation development. Women entrepreneurs often face gender-based barriers to starting and growing their businesses, like discriminatory property, matrimonial and inheritance laws and or cultural practices, lack of access to formal finance mechanisms, limited mobility and access to information and networks, etc. Women's entrepreneurship can make a particularly strong contribution to the economic well-being of the family and communities, poverty reduction and women's empowerment, thus contributing to the Millennium Development Goals (MDGs). Thus, governments across the world as well as various developmental organizations are actively undertaking promotion of women entrepreneurs through various schemes, incentives and promotional measures.
\end{abstract}

Keywords: Women entrepreneurship, dynamics, micro small and medium enterprises, skill development, policy initiatives.

Women entrepreneurs may be defined as a women or group of women who initiate, organise and run a business enterprise. The Government of India has defined Women Entrepreneurs based on women participation in equity and employment of a business enterprise. Accordingly women entrepreneur is defined as an enterprise owned and controlled by a women having a minimum financial interest of 51 per cent of the capital and giving at least 51 per cent of the employment generated in the enterprise to women. The term "Women Entrepreneurship", is an act of business ownership and business creation that empowers women economically, increases their economic strength as well as position in society. Women entrepreneurs create new jobs for themselves and others and can provide society with different perspectives and approaches to management, organisation and business issues" (OECD, 2004).

The role of Women Entrepreneurship in the emergence of entrepreneurs in a society depends to a great extent on economic, social, religious, cultural and psychological factors prevailing in the society. There is a crucial need to recognize the talent of women and give them a requisite platform to start their business in order to show their visibility in the economy. The objective of this study is to find out the factors that impact upon the women entrepreneurs in their social and economic development.

\section{Objectives of the Study}

To study the dynamics of women entrepreneurship in India.

To study the impact of ICT on women entrepreneurship

To highlight the ICT initiatives for prospective women entrepreneurs.

To find out the challenges of women entrepreneurship 
To provide the strategic steps for entrepreneurship development among women

To provide recommendations for the policy makers and heads of the institutions.

\section{Determinants of Women Entrepreneurship}

Entrepreneurship in developing countries has been subject to numerous studies (van der Sluis et al. 2005; Ardagna and Lusardi, 2008; Schoar 2009). Many barriers to entrepreneurship, such as the business environment, affect both genders. There is also a growing literature on woman entrepreneurship (Minniti 2010; Kobeissi 2010) and especially on India (Ghani et al. 2012, 2013, 2014) attempting to identify factors more definite to woman entrepreneurship. These studies have identified education, income per capita, infrastructure, family situation, selfperceptions, or political representation as decisive to woman entrepreneurship. Agglomeration and network benefits have also been deemed important (Ghani et al. 2012) (Note: As per OECD, 2015.).

\section{Types of Women Entrepreneurs}

Entrepreneurship Development Institute of India, Ahmedabad defines that a major stratification of women entrepreneurs can be made as follows:

Chance Entrepreneurs: These entrepreneurs start business without any preparation, clear goals or plans. They happen to grab the opportunities which they come-across.

$\square$ Forces Entrepreneurs: These entrepreneurs start business due to some mishaps in their families like death of father or husband, divorce etc.

Created Entrepreneurs: These entrepreneurs are properly identified, motivated, encouraged and developed through EDPs as a part of a strategy to develop women as competent entrepreneur.

\section{Definition of Micro, Small and Medium Enterprises (MSMEs) in India}

The MSMEs are defined on the basis of investment in Plant \& Machinery and Equipment under the MSMED Act, 2006. The present investment limit for MSMEs is as under:

\section{Manufacturing Enterprises}

(i) Micro Enterprise: Investment in Plant and Machinery upto ₹ 25 lakh

(ii) Small Enterprise: Investment in Plant and Machinery from ₹ 25 lakh to ₹ 5 Crore.

(iii) Medium Enterprise: Investment in Plant and Machinery from ₹ 5 Crore to ₹ 10 Crore

\section{Service Enterprises}

(i) Micro Enterprise: Investment in Equipments upto ₹ 10 lakh.

(ii) Small Enterprise: Investment in Equipments from ₹ 10 lakh to ₹ 2 Crore

(iii) Medium Enterprise: Investment in Equipments from ₹ 2 Crore to ₹ 5 Crore.

\section{Women Entrepreneurship Policies in India}

The Ministry of Women and Child Development has several ambitious programs for female selfemployment: Support to Training \& Employment Programme for Women (STEP) was launched in 1986 to help groups of vulnerable women to set up their own business to get out of poverty and improve their social status.

The first stage of the process is the creation of a Self Help Group (SHG) that will help women to build self-confidence and give them a first experience of money management by collection of savings and lending to individual members. A business plan is then prepared by a non-government organization (NGO) with a focus on traditional sectors of employment relevant to the specific area. Members of the SHG then receive suitable vocational training, and fixed assets as well as working capital requirements are financed jointly through a government grant and the NGO grant/ loan or a bank loan.

Government subsidies are then phased out over a period of 5 years with the ultimate goal of selfsufficiency. STEP also provides support services such as health check-ups and child care for the duration of the project, and organizes general awareness programs about nutrition and gender issues.

The National Credit Fund for Women, also known as Rashtriya Mahila Kosh (RMK) was set up in 1993 provides access to micro-credit to poor Indian 
women, by making loans to microfinance institutions (MFI) involved in women empowerment. Nonprofit organizations can apply for a loan from RMK, including NGOs, Cooperative societies, Government organizations, or State Women Development Corporations (state-level equivalents of the Ministry of Women \& Child Development), provided the organization has sufficient experience in credit management. RMK also finances agricultural vocational trainings through a dozen partner institutions across India.

The Swayam Sidha Scheme, also known as Integrated Women Empowerment Programme was launched in 2001 and ended in 2008, its objectives are similar to STEP, except that it put more emphasis on the first stage of STEP. After the creation of the initial SelfHelp Groups, the Swayam Sidha Scheme requires the SHGs to federate into Village Societies, including representatives of each SHG and local functionaries. The Village Societies will then federate into Block Societies, (the block being the administrative unit directly under the district) that can ask for registration as non-profit society. The aim is to strengthen the links between women SHGs to make them more powerful. This hierarchical structure is also meant to provide a single channel for the delivery of the various schemes of the Ministry of Women and Child Development.

Besides actions of the Ministry of Women and Child Development, certain schemes of the Ministry of Micro, Small and Medium Enterprises (Ministry of MSME) and its Development Commissioner, give preferential treatment to women. This preferential treatment is usually shared with SC/ST categories, North-Eastern states, and sometimes with microenterprises (defined in terms of the size of fixed assets). Under the Prime Minister's Employment Generation Programme (PMEGP) discussed in Box 2 the share of the government grant in setting up a micro-enterprise rise from $15 \%$ to $25 \%$ in urban areas and from $25 \%$ to $35 \%$ in rural areas when the beneficiary is a woman. Additionally, the share of the project cost to be supported by the beneficiary drops from $10 \%$ to $5 \%$, the remaining $70 \%$ to $60 \%$ being covered by a bank loan.

Under the Micro and Small Enterprises - Cluster Development Programme (MSE - CDP) created in 2007, clusters with more than $50 \%$ of femaleowned enterprises benefit from a government grant of $90 \%$ for "Soft Interventions" (organization of training sessions and seminars, hiring of business consultants etc.) and for "Hard Interventions" (creation of common facility centres, such as testing centres, warehouses, effluent treatment plant etc.) instead of a government grant of respectively $75 \%$ and $70 \%$ for low-priority clusters. The government grant is also raised to $80 \%$ (instead of $60 \%$ ) for "Infrastructure Development" (construction of roads, power or water distribution networks etc.) and the minimum threshold to benefit from soft interventions is lowered from 25 to 20 cluster units. Under the Credit Guarantee Fund Scheme for Micro and Small Enterprises, launched in 2000, the guarantee cover for women-owned businesses in case of default is extended to $80 \%$ of the bank loan instead of $75 \%$.

The Trade Related Entrepreneurship Assistance and Development (TREAD) for Women aims at improving access to credit for female entrepreneurs in non-agricultural activities. The objective is to mobilize the help of local NGOs to formulate business plans and obtain bank loans for one or several female entrepreneurs, and provide technical training and business advice. The government grant amounts to $30 \%$ of the total project cost, which in the guidelines of TREAD includes not only fixed assets and working capital but also training and consultancy fees and participation in product exhibitions.

The Mahila Coir Yojana, managed by the Coir Board under the Ministry of MSME: was launched in 1994 to modernize the traditional industry of the coir fibre by providing technical training and subsidies for the use of motorized spinning machines. Only women are eligible for assistance. They first receive a two-months training on the new equipment assorted with a training stipend, and the spinning machine is then purchased using a $75 \%$ government subsidy.

SIDBI has also its own scheme for women entrepreneurs, namely the Mahila Udyam Nidhi Scheme to make subsidized loans to female entrepreneurs in small-scale businesses. New businesses as well as existing businesses can apply for assistance to upgrade technology, increase of production capacity or financial bailout. The soft loan (subsidized loan) is not to exceed $25 \%$ of the project cost, while the remaining $65 \%$ (taking into 
account the beneficiary's own contribution of 10\%) can be financed under the usual SIDBI loan policy.

Finally, the Ministry of Rural Development and the Ministry of Housing and Urban Poverty Alleviation have designed a preferential treatment for women through their own self-employment schemes (respectively the Swarna Jayanti Gram Swarozgar Yojana and the Swarna Jayanti Shahari Rozgar Yojana). These schemes are analogous to PMEGP but they each apply to rural or urban areas only. The Ministry of Rural Development has issued guidelines stating that women should constitute no less than $40 \%$ of the beneficiaries, and the Ministry of Housing and Urban Poverty Alleviation has provided for a women-specific component of its own scheme similar to STEP.

\section{Impact of ICT on Women Entrepreneurship}

ICT emerging as an increasingly valuable business tools for women entrepreneurs. It is essential that women entrepreneurs must equipped themselves with these set of techniques for effective use of such technology for the achievement of business goals that leads to the achievement of ultimate aim of MDGs.

Dynamic changes in ICT landscape, in terms of infrastructure, new innovations, and institutional norms impended challenges upon women entrepreneurs potential to start, and grow business in this era of globalization.

In India, over 110 million women are active users of internet and growing at a rate of $46 \%$ for females, according to a report by Internet and Mobile Association of India and IMRB International.

Urban India isn't just witnessing women's contribution to social change, health care and education. There are a considerable number of initiatives undertaken by rural women at the grass root level too in spreading awareness for gender equality.

Women village-level entrepreneurs run a range of Common Service Centres in India. Vaijanti Devi, who hails from Bihar, runs one such centre and offers online banking services and enrolls villagers for the Aadhar programme.

1. It empowers women entrepreneurs through application of information and communications technologies.
2. ICT enables access to markets, ownership and technology by allowing women entrepreneurs to seize new market opportunities to create jobs and be competitive and sustainable.

3. E-commerce which involves the buying and selling of goods and services on the internet or other electronic platforms is making it possible for micro-entrepreneurs to engage in trade by creating virtual store on websites for the global market.

4. Women entrepreneurs are now using mobile phones, SMS, email and internet based telephony such as skype to connect with customers, business associates and partners.

\section{ICT Initiatives for Women Entrepreneurs}

\section{ICT Initiative "SAKSHAM - Power of SHE"}

To support and encourage entrepreneurship among women, National Institute of Electronics and Information Technology (NIELIT), a body with the Ministry of Electronics and Information Technology, has launched an initiative 'Saksham - Power of She,' aimed at encouraging entrepreneurship among women under 'Digital India'. Over 200 female students from NIELIT Centres across different geographical locations participated through smart virtual classrooms that facilitate live interactive session through video conference. The students who are in the process of acquiring industry relevant skill sets in IT and electronics, were sensitised about entrepreneurship.

\section{IT for Masses scheme for Women}

NIELIT Delhi Centre is providing free training to women candidates under a Diet Y (Department of Electronics and Information Technology) sponsored project titled "IT for masses for Women".

Under this scheme free training is being provided to women with low income group (Annual income upto 5 lacs). Women candidates with minimum $8^{\text {th }}$ qualification are being trained in basic e-literacy programme (BCC), Undergraduate women are being trained as Data Entry operators (CCC and Typing with introduction to Tally) "Training of Women in Delhi for creating women Entrepreneurs/ Data Entry operators with an exposure to Tally, to promote awareness and to enhance vocational skills of women". 


\section{Digital India}

Digital India aims to transform India into a digitally empowered society and knowledge economy. A beginning has already been achieved, with the first Women Village Level Entrepreneur Conference that was held in March 2015.

Other programmes include Arogya Sakhi, which is a mobile application that assists women entrepreneurs to deliver preventive health care at the doorstep. Similarly, Internet Saathi aims to deploy 1,000 specially-designed bicycles with connected devices to give women a chance to experience the Internet for four to six months.

\section{Women Entrepreneurs in India}

\section{Structural Indicators}

Total number of establishments owned by women entrepreneurs was 8.05 million (13.76\%). These establishments provided employment to 13.45 million persons (10.24\%), out of which $83.19 \%$ were without hired workers. About $88.8 \%$ of the workers were employed in the establishments hiring less than 10 workers. Total number of Self Help Groups (SHGs) were 0.19 million out of which all women Own Account Establishments were 89\%.

1. Out of establishments under women entrepreneurs, about $34.3 \%$ belonged to agricultural activities, with livestock dominating therein having a share of $31.6 \%$. Among non-agricultural activities owned by women entrepreneurs, manufacturing and retail trade were the dominant ones with corresponding percentages being $29.8 \%$ and $17.8 \%$ respectively.

2. Out of the total establishments under women entrepreneurs, percentage share of various social and religious groups was as follows: OBC: $40.60 \%$, SC: $12.18 \%$, ST: $6.97 \%$ and Others (40.25\%); Hindus: 65.6\%, Muslim: 12.84\% and Christian: $5.2 \%$.

3. Among the states, the largest share in number of establishments under women entrepreneurship was held by Tamil Nadu (13.51\%) followed by Kerala (11.35\%), Andhra Pradesh (10.56\%), West Bengal (10.33\%) and Maharashtra (8.25\%).
4. Average employment per establishment for women owned establishments was found to be 1.67 .

Note: Annual Report 2016-17, Contribution of Different Sectors to Gross Value Added in 2015-16, Ministry of Statistics and Programme Implementation, Government of India

As per the Sixth Economic Census, there are a total of 8050819 establishments under women entrepreneurs in India. This figure provides the state-wise breakup of the percentage of establishments under women entrepreneurship for every state. As can be seen, Tamil Nadu has the highest percentage of women entrepreneurs at $13.5 \%$ out of the total establishments within the state, whereas UTs and North Eastern states rank at the bottom.

The top five economic activities as per establishments owned by women were:

(i) Agriculture (34.3\%)

(ii) Manufacturing (29.8\%)

(iii) Trade $(18.23 \%)$

(iv) Other services (5.38\%) and accommodation and food services $(2.77 \%)$

While these numbers are encouraging, significant work is required to increase percentage of women entrepreneurship within the country.

Table 1: Percentage Share of Establishments with Women Entrepreneur

\begin{tabular}{cc}
\hline State & $\begin{array}{c}\text { Percentage Share of } \\
\text { Establishments with } \\
\text { Women Entrepreneur }\end{array}$ \\
\hline Tamil Nadu & 13.51 \\
Kerala & 11.35 \\
Andhra Pradesh & 10.56 \\
West Bengal & 10.33 \\
Maharashtra & 8.25 \\
Karnataka & 6.78 \\
Gujarat & 6.57 \\
Uttar Pradesh & 5.99 \\
Telangana & 4.43 \\
Odisha & 3.1 \\
Rajasthan & 3.08 \\
Madhya Pradesh & 2.77 \\
Assam & 1.91
\end{tabular}




\begin{tabular}{cc} 
Bihar & 1.91 \\
Haryana & 1.55 \\
Punjab & 1.38 \\
Manipur & 1.1 \\
Chhattisgarh & 0.97 \\
Delhi & 0.87 \\
Jharkhand & 0.68 \\
Himachal Pradesh & 0.61 \\
Uttarakhand & 0.39 \\
Jammu \& Kashmir & 0.39 \\
Meghalaya & 0.37 \\
Goa & 0.21 \\
Mizoram & 0.2 \\
Tripura & 0.18 \\
Nagaland & 0.17 \\
Puducherry & 0.13 \\
Arunachal Pradesh & 0.08 \\
Sikkim & 0.07 \\
Chandigarh & 0.07 \\
A\& N Islands & 0.03 \\
D\& N Haveli & 0.02 \\
Lakshadweep & 0.01 \\
Daman\& Diu & 0.01 \\
\hline
\end{tabular}

Source: Annual Report 2016-17, Ministry of Micro, Small and Medium Enterprises, Govt. of India.

\section{Chart No. 1}

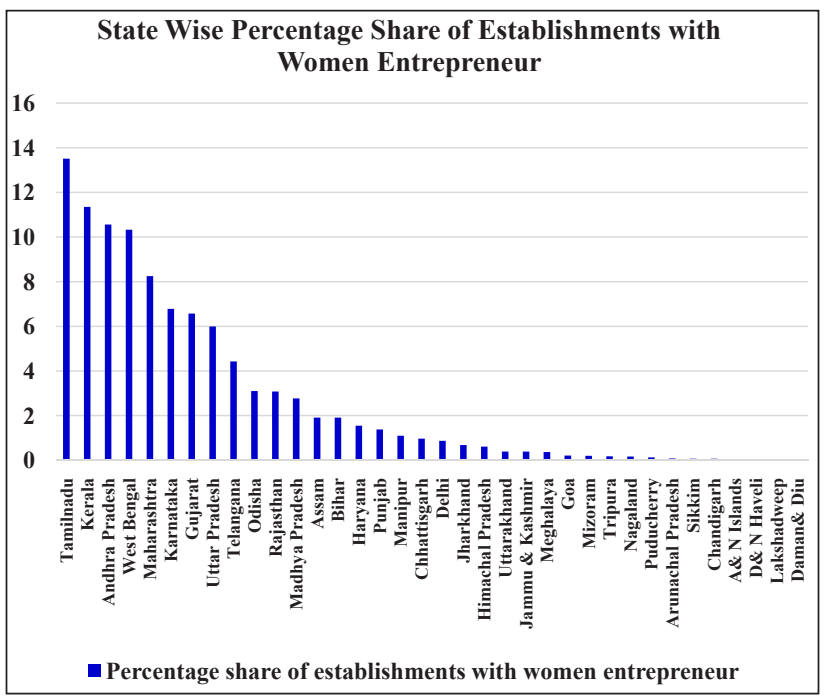

Source: Annual Report 2016-17, Ministry of Micro, Small and Medium Enterprises, Govt. of India.

\section{Sources of Financing of Women Entrepreneurs}

The sixth economic census provides details of the sources of financing of women entrepreneurs. As can be seen, most women entrepreneurs are selffinancing their establishments.

There is therefore a need to ensure women have better access to formal governmental channels of finance.

About $70 \%$ of the employees of India largest apparel exporters are women. Recent studies have estimated that India GDP would grow by an additional 1.4 percent every year if women were to participate as much as men in the economy.

Chart No. 2

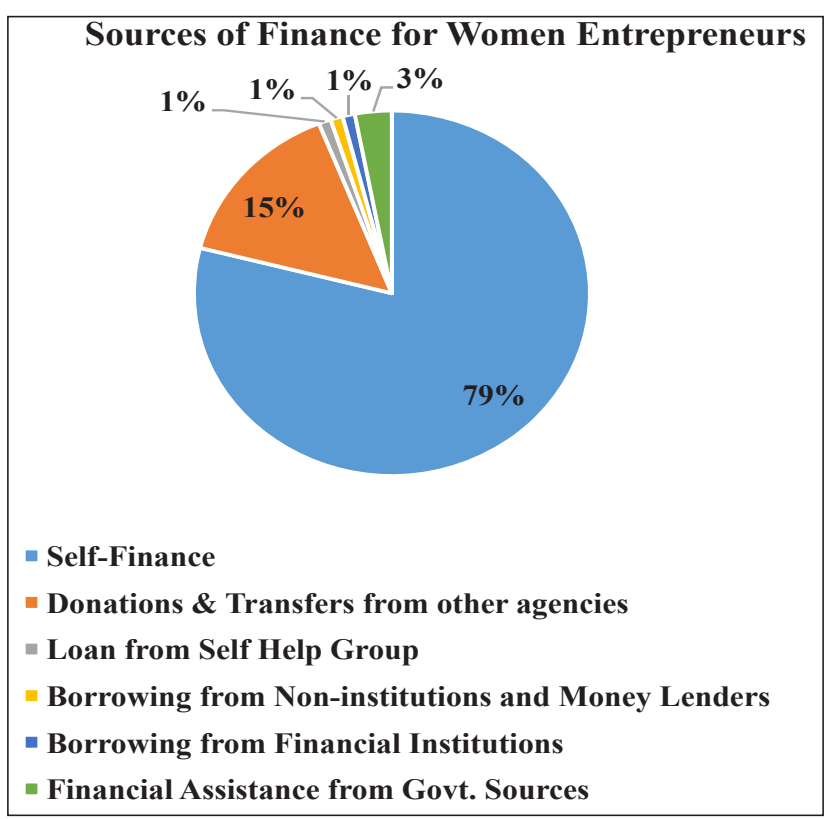

Source: Annual Report 2016-17, Ministry of Micro, Small and Medium Enterprises, Govt. of India.

\section{Major Schemes of the Ministry of Micro, Small and Medium Enterprises}

The ministry of MSME runs numerous schemes targeted at skill development, financial assistance, technological assistance and quality upgradation of MSME. The schemes related to women entrepreneurship and development are as follows:

\section{Scheme for providing financial assistance to set} up new enterprises under PMEGP: Objectives :

The scheme aims to generate employment opportunities in rural as well as urban areas of the country through setting up of new self-employment ventures, projects, micro enterprises. 
To provide continuous and sustainable employment to a large segment of traditional and prospective artisans and rural and urban unemployed youth in the country, so as to arrest migration of rural youth to urban areas.

$\square$ To increase the wage earning capacity of artisans and contribute to increase in the growth rate of rural and urban employment.

Implementation of the scheme: The scheme is implemented by khadi and village industries commission as the nodal agency at the national level.

Maximum Cost of the project admissible under the scheme: For manufacturing sector is ₹ 25 lakh and for business and service sector is ₹ 10 lakh.

\section{Current Status of the project}

\begin{tabular}{cccc}
\hline $\begin{array}{c}\text { Time } \\
\text { Period }\end{array}$ & $\begin{array}{c}\text { Units } \\
\text { Established }\end{array}$ & $\begin{array}{c}\text { Employment } \\
\text { (in persons) }\end{array}$ & $\begin{array}{c}\text { Funds } \\
\text { Allocated (in ₹ } \\
\text { Crore) (2016-17) }\end{array}$ \\
\hline $\begin{array}{c}\text { 2014-15 to } \\
\text { 2016-17 }\end{array}$ & $1,20,673$ & 8,90408 & $1120.0(\mathrm{RE})$ \\
(upto 31.12. & & & \\
2016) & & & \\
\hline
\end{tabular}

Relaxation is provided to women beneficiaries under prime minister Employment generation programme (PMEGP). Since inception 2008-09 to 31.12 . 2016, 91,083 projects have been assisted to women entrepreneurs under PMEGP. Data on number of women beneficiaries for each year over the past five years is as follows:

Table 2: PMEGP

\begin{tabular}{cc}
\hline Year & Women Beneficiaries \\
\hline $2011-12$ & 14299 \\
$2012-13$ & 13612 \\
$2013-14$ & 13448 \\
$2014-15$ & 13394 \\
$2015-16$ & 7508 \\
2016-17 (upto 31.12.2016) & 3178 \\
\hline
\end{tabular}

ASPIRE - A Scheme for Promotion of Innovation, Rural Industry \& Entrepreneurship

\section{Objectives of the Scheme}

1. Create new jobs and reduce unemployment

2. Promote entrepreneurship culture in India
3. Grassroots economic development

4. Facilitate innovative business solution for unmet social needs and

5. Promote innovation to strengthen the competitiveness of MSME sector.

Chart 3: Women Beneficiaries under PMEGP 2011-16

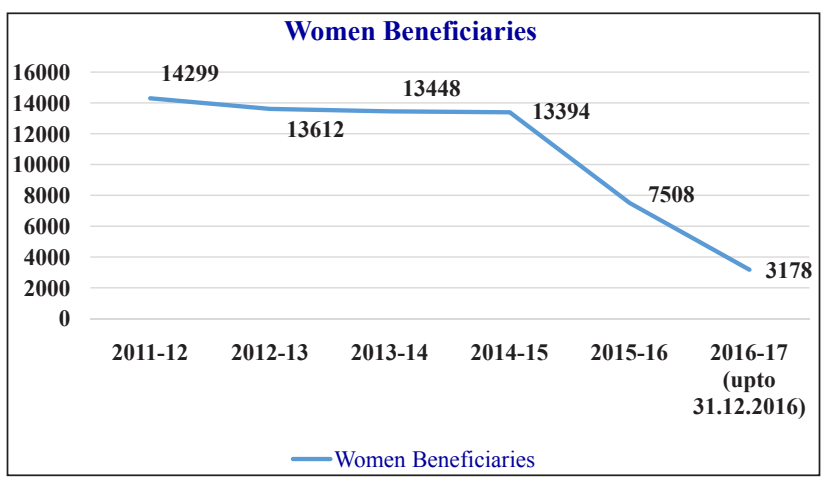

Note: Provisional Estimate for 2016-17 (upto December 31 ${ }^{\text {st }}$, 2016) is 3178

Source: Annual Report 2016-17, Ministry of Micro, Small $\mathcal{E}$ Medium Enterprises, Government of India, New Delhi,

\section{Components of the scheme}

Create a framework for startup promotion through small industries development bank of India by using innovative means of finance to enable ideas and innovation to convert these into commercial enterprises.

Status: The scheme was introduced in 2015-16. As on 31.12.2016, 50 Livelihood business incubators (LBIs) and 5 Technology Business Incubator (TBIs) proposals have been given approval out of which 21 LBIs have been operationalized.

Total support to be provided to these 55 incubators is ₹ 41.11 Crore.

\section{Intended Beneficiaries}

1. Existing incubation centres or institutions operating under different ministry and department of govt of India.

2. New incubation centres, private institutions, industry associations, academic institutions, R\& D laboratories, Universities, Government entities and technology parks.

\section{Implementation}

ARI- Agro and Rural Industry Wing, NSIC- 
National Small Industries Corporation, KVIC- Khadi Village industries commission, Coir Board are nodal agencies.

Funds Allocated: 20.00 (In ₹ Crore) (2016-17) (RE) (Revised Estimates)

\section{TREAD- Trade Related Entrepreneurship Assistance and Development Scheme to Women}

This scheme is meant for economic empowerment of women through trade related training, information and counselling activities for trade, products and services etc. This scheme provides financial loans through ngos who are also provided GOI Grant for capacity building.

Women entrepreneur benefitted under the scheme set up their own enterprises for undertaking nonfarm activities like food processing, readymade garments and tailoring, paper and leaf cup plates, beauty parlours etc.

Table 3: Number of Women Benefitted under the TREAD Scheme and Grants Released

\begin{tabular}{ccc}
\hline Year & $\begin{array}{c}\text { Number of Women } \\
\text { Benefitted }\end{array}$ & $\begin{array}{c}\text { Total Grant Released } \\
\text { (₹ In crore) }\end{array}$ \\
\hline $2014-15$ & 8265 & 2.54 \\
$2015-16$ & 3560 & 2.00 \\
$2016-17$ & 5000 (proposed) & Nill till 31.12.2016 (BE \\
& & 3.00, RE 2.42) \\
\hline
\end{tabular}

Source: Annual Report 2016-17, Ministry of Micro, Small and Medium Enterprises, Government of India

\section{Skill Development Initiative}

Skill Development Initiative by Department of Industrial Policy and Promotion, Ministry of Skill Development and Entrepreneurship, Government of India, in an endeavor to create a conducive socialcultural and economic environment for women. The special focus of this initiative is to skilling and empowering women. For this, several initiatives have been taken to further strengthen the ecosystem.

1. $30 \%$ of all the seats are reserved in all Govt. and Private ITIs for courses for women candidates which includes girls as well.

2. 5 new RVTIs (Regional Vocational Training Institute) for women in Skill Development have been established during FY 2015-16 and 3 are to be opened in FY 2016-17. 2 RVTIs are being established in Himachal Pradesh (Jhundla, Shimla) and Tripura (Anandanagar, Agartala) to facilitate the requirements in the hilly terrain since august 2015.

3. NSDC (National Skill Development Corporation) training partners have trained a total of 155,236 Women Candidates across India of which 54,456 have been placed as on October 31, 2016.

\section{Challenges of Women Entrepreneurship}

Women in India deals with various challenges to achieve their life goals and the very challenge start from its family and society to support for accomplishment of their dreams. Indian Patriarchal society cultural restricts women growth in an economy. Social norms limits the women development in terms of their participation in an economic activity.

Lack of proper education and knowledge of skills required to become a successful entrepreneur. Financial instability is also the case for a women entrepreneurs. Business involves uncertainty and risk and women entrepreneurs unable to cope with it due to lack of entrepreneurial abilities.

Ineffectiveness in policy instruments of government to raise women entrepreneurship. The entrepreneurial culture in a country affects the attitude that individuals have towards entrepreneurship. The prospect of choosing entrepreneurship as a career, depends upon the drive to success and to start again after a failure of business.

The low presence of women on company boards is often cited as a signal of the obstacles women face in climbing the corporate ladder. The regulatory framework is a crucial factor affecting entrepreneurial performance. It attached with Starting a business, dealing with construction permits, getting electricity, registering property, getting credit, credit information, protecting investors, paying taxes, trading across borders, enforcing contracts, resolving insolvency, and employing workers. A combination of opportunity, capabilities and resources does not necessarily lead to women entrepreneurship. 


\section{Recommendations}

1. The first and foremost, education is of prime importance for women's in order to accelerate their talent. Incite among young women's to pursue higher education.

2. Provide equal opportunities to women in work field for their self-development and empowerment.

3. To curb Gender based inequality requires the greater attention of the policy makers.

4. Increase the quota for women in the parliament to exhibit the visibility and power of women in a democratic India.

5. Training and Development programs for prospective women entrepreneurs should be organized at regular intervals and there must be proper monitoring of that also to ensure their participation.

6. The benefits of various government schemes and programs must reach to the women entrepreneurs through or by awareness camps at remote villages of India so that they can avail the advantage of it

7. Provide a conducive external environment for women entrepreneurs to enable them to achieve effective utilization of available resources.

\section{CONCLUDING REMARIS}

Women in India deals with so many challenges on the part of societal mind setups and thoughts. A lack of adequate knowledge and skills required for entrepreneurship is often considered to be one of the most significant barriers to the formation of business enterprise. Entrepreneurship skills are an accumulation of skills that includes planning, organizing, financial management, and personal traits like self-initiative and the ability to deal risks and uncertainty. Although entrepreneurship skills are not always necessary to operate a successful business entity it generally enhance the possibility of survival and growth of business. In the case of women entrepreneurs, pre-marital involvement to entrepreneurial activities within the family and support from the spouse as well as relatives and friends plays a positive role. Women entrepreneurship represents a status of women in India in terms of their contribution to various sectors of an economy and thus leads towards gross domestic product. They play a very significant role in nation development. There is a need to be responsible about women development by the family, society, government and public at large then only women entrepreneurship developments is attainable.

\section{REFERENCES}

Adams, R.B. and Ferreira, D. 2009. "Women in the boardroom and their impact on governance and performance", Journal of Financial Economics, 94(2): 291-309.

Ahmad N. and Hoffman, A. 2008. "A Framework for Addressing and Measuring Entrepreneurship," OECD Statistics Working Papers 2008/2, OECD Publishing.

Awasthi, D. 2011. "Approaches to Entrepreneurship Development: The Indian Experience", Journal of Global Entrepreneurship Research, 1: 107-124.

Boegh Nielsen, P. 2001. "Statistics on Start-ups and Survival of Women Entrepreneurs: the Danish Experience" in Women Entrepreneurs in SMEs, Realising the Benefits of Globalisation and the Knowledge-based Economy, OECD Publishing.

Bosma N., Wennekers, S. and Amorós, J.E. 2012. Global Entrepreneurship Monitor Extended Report 2011: Entrepreneurs and Entrepreneurial Employees Across the Globe.

Swarajya Lakshmi, C. (ed.), 1999. Development of Women Entrepreneurship in India: Problems and Prospects, Discovery Publishing House, New Delhi.

Charumati, B. 1998. "Women Entrepreneurs Challenges and prospects", Classical Publishing Company, New Delhi.

Eurostat/OECD 2007. Eurostat-OECD Manual on Business Demography Statistics, OECD Publishing.

Field, E. S. Jayachandran, and Pande, R. 2010. “Do Traditional Institutions Constrain Female Entrepreneurship? A Field Experiment on Business Training in India", American Economic Review, 100: 125-129.

Gupta, V.K., Turban, D.B., Wasti, S.A. and Sikdar, A. 2009. "The Role of Gender Stereotypes in Perceptions of Entrepreneurs and Intentions to Become an Entrepreneur", Entrepreneurship Theory and Practice, 33: 397-417.

Kelley D.J., Bosma, N. and Amorós, J.E. 2011. Global Entrepreneurship Monitor Report 2010.

Kobeissi, N. 2010. “Gender factors and female entrepreneurship: International evidence and policy implications", Journal of International Entrepreneurship, 8: 1-35.

Letowski, A. 2001. "Comment améliorer la connaissance statistique des femmes chefs d'entreprise?", in "Women Entrepreneurs in SMEs, Realising the Benefits of Globalisation and the Knowledge-based Economy", OECD Publishing. 
McBride, M. 2013. "India: A heartless nation for women”, Asian Human Rights Commission, Hong Kong.

Minniti, M. 2010 "Female Entrepreneurship and Economic Activity", European Journal of Development Research, 22: 294-312.

Minniti, M. and Naudé, W. 2010. “What Do We Know about the Patterns and Determinants of Female Entrepreneurship across Countries?" European Journal of Development Research, 22: 277- 293.

OECD 2004. Women Entrepreneurship, Issues and Policies, OECD Publishing.

OECD 2012. Entrepreneurship at a Glance 2012, OECD Publishing.

OECD 2013. Entrepreneurship at a Glance 2013. Paris.
OECD/EU 2014. "Self-employment and entrepreneurship activities by women," in The Missing Entrepreneurs 2014: Policies for Inclusive Entrepreneurship in Europe, OECD Publishing, Paris.

OECD 2012. "Birth and death rates of women-owned enterprises", in Entrepreneurship at a Glance 2012, OECD Publishing, Paris.

Ravi, S. 2009. "Entrepreneurship Development in the Micro, Small and Medium Enterprise Sector in India", Indian School of Business, www.isb.edu

Statistics Norway 2011. "Ownership and roles in business enterprise sector", www.sbb.no/eigazskap_en.

Erik Monsen, Prashanth Mahagaonkar and Christian Dienes, 2012. Entrepreneurship in India: the question of occupational transition, Small Business Economics, 39(2): 359. 